\title{
砂利道床軌道が走行車両より受ける衝撃の測定および解析 MEASUREMENT AND ANALYSIS OF THE IMPACTS APPLIED TO THE RAILWAY TRACK UNDER THE RUNNING VEHICLES
}

\section{1. 緒言}

著者らはすでに走行列車によって砂利道床軌道に生ず る振動を測定し，解析した結果を述べだ)。この振動は レール面または車輪踏面に存在する無数の微少な傷に よって生ずると推定される。今回は特にレール面または 車輪踏面に顕著な傷が存在する場合について軌道が受け る衝撃を測定し,その発生頻度ならびに車両動摇による 荷重変動との関連について研究を行った。

軌道にもっとも大きな衝撃を加えるのは車輪踏面にフ ラット部がある場合と推定されるので人工的に車輪に大 きなフラット部を作り走行試験を実施した結果が鉄道技 術研究所より発表されている2) 4)。軌道に欠陥がある場 合としてはレールの継目落ちが挙げられ、レール継目部 付近におけるレール圧力の変動を測定した結果がすでに 発表されている5)。また東海道新幹線の軌道落ち込み箇 所を高速で試験電車が走行したときに $40 \mathrm{t}$ に近い著大

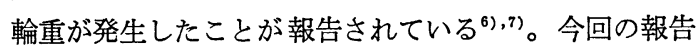
は一般の通過車両ならびに在来線軌道に通常存在する欠 宿部によって軌道が受ける衝撃を測定することに重点を おいた。

\section{2.レール面の欠陥によって軌道が受ける 衝撃の測定}

レール面がすべり易い場合には多数の車両を㐿引した 機関車が出発するときに動輪がレール面上で空転するこ とがある。そのときレール面に空転傷を作り，その一例 を図一1に示した。この箇所を D 51 型機関車が種々の 速度で通過した場合に軌道が受ける衝撃を測定した。軌 道構造としては $37 \mathrm{~kg} 25 \mathrm{~m}$ レール，木まくらぎ $37 丁$

* 正会員 工博 金沢大学教授 工学部土木工学科 ** 正会員 石川工業高等尃門学校助手 土木工学科
小野 一 良*・伊 藤 義 男**

By Kazuyoshi ONO and Yoshio ITO

配置, タイプレートなし, ふるい砂利道床, 直線平坦線 であった。

空転傷の直下においてレール底部にワイヤストレイン ゲージを貼り，レールに生ずる曲げ応力を測定した。そ の記録を図一2に示すが，低速度においてはまず負の衝 撃が加わり，これに続いて大きな正の衝撃が加えられ る。しかし速度が増すと負の衝撃は増すが, 正の衝撃は 次第に目立たなくなってくる。これは高速になると車輪 が空転傷を飛び越えて進むためと考えられる。先輪の通

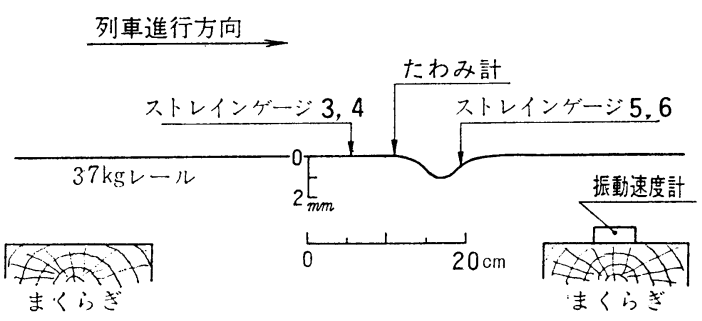

図一1 レール面に生じた空転儌
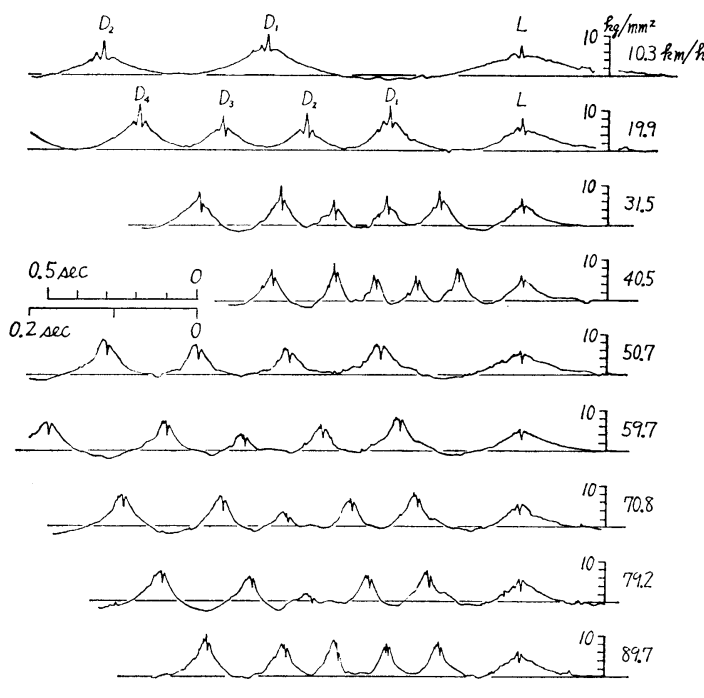

図一2 空転偤のあるレールに生した曲げ応力の測定記録 
過時にレールに生ずる正負の衝撃による曲げ応力の大き さと列車速度との関係を図一3に示した。低速において は正の衝撃による曲げ応力が静的曲げ応力の $70 \%$ にな る場合がある。

次に空転傷の直下においてレールのたわみを測定した 記録例を図一4の上部に示し，先輪の通過時におけるた わみの変化と走行速度との関係をその下に示した。

図一3，4 亿よればいずれも走行速度 $20 \mathrm{~km} / \mathrm{h}$ のとき に衝撃が最大值に達し，それより速度が増加するときに 衝撃が減少することを示している。しかし図一3によれ ば速度 $40 \sim 50 \mathrm{~km} / \mathrm{h}$ において衝撃浪低となり，それ

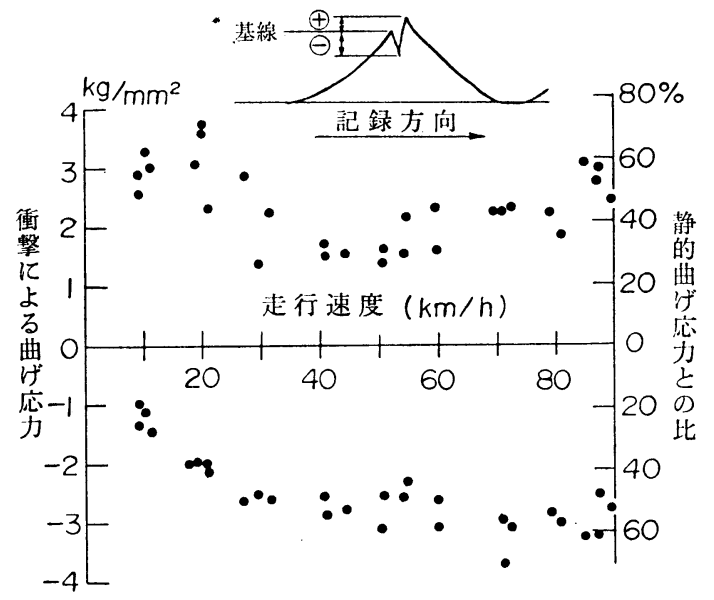

図一3空転侮によりレール底部に生ずる曲げ応力

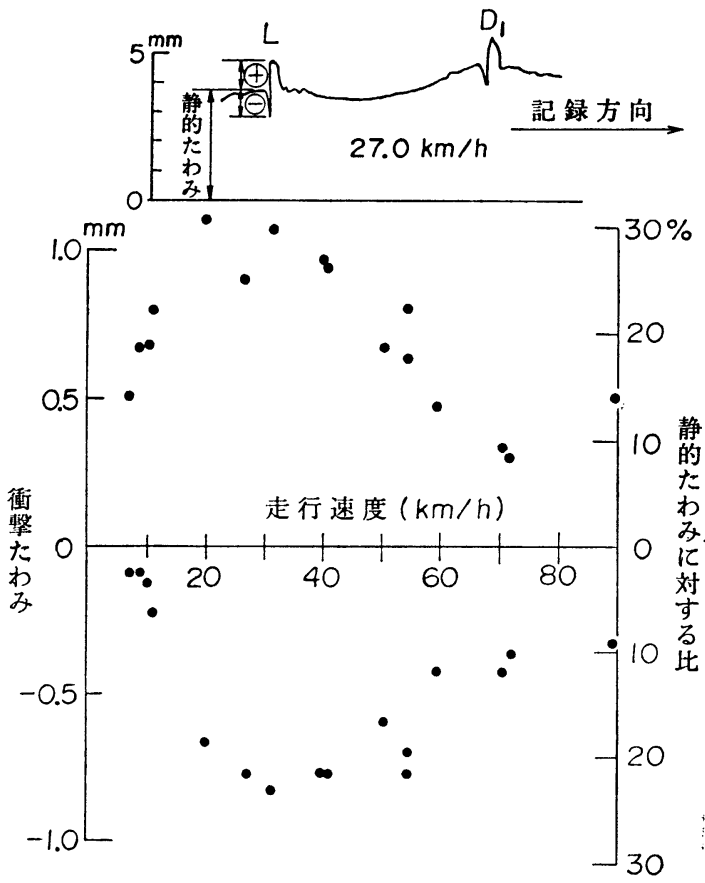

図一4 空転箇によるレールの衙繋たわみ
より速度の増加とともにいくぶん増加するが，図一4 に よれば衝撃は速度 $70 \sim 80 \mathrm{~km} / \mathrm{h}$ に至るまで次第に減少 している。また一般に曲げ応力より得た衝撃值がたわみ より得た衝撃値よりはるかに大きい。このような差を生 じた原因として考えられることはレール底部に生ずる曲 げ応力の值は荷重が測定位置を離れると急速に低下する ため静荷重の大きさも衝撃値もその載荷点において測定 した曲げ応力より求めなければならない。このような位 置を予想してワイヤストレインゲージを貼り付けたので あるが, 列車速度の変化によって最大の衝撃の作用する 位置にいくらかのずれがあり，また図一3の上部に示し たように負の衝撃を生ずる直前の曲げ応力を静荷重によ る曲げ応力として基線を引き，この基線を基準として正 負の曲げ応力を求めたことにも問題があったと考えられ る。

これに反しレールのたわみは荷重が測定箇所をいくら かはずれても大きな変化はないので比較的に正確に求め られる。しかしたわみの測定機構の中に機械的部分があ るので急激な変化に対しいくらか慣性の影響が入るおそ れがあった。また静的たわみの中にはレールとまくらぎ およびまくらぎと道床との間の嚐が入るためたわみの大 きさ满重の大きさに比例しない。したがって衝撃荷重

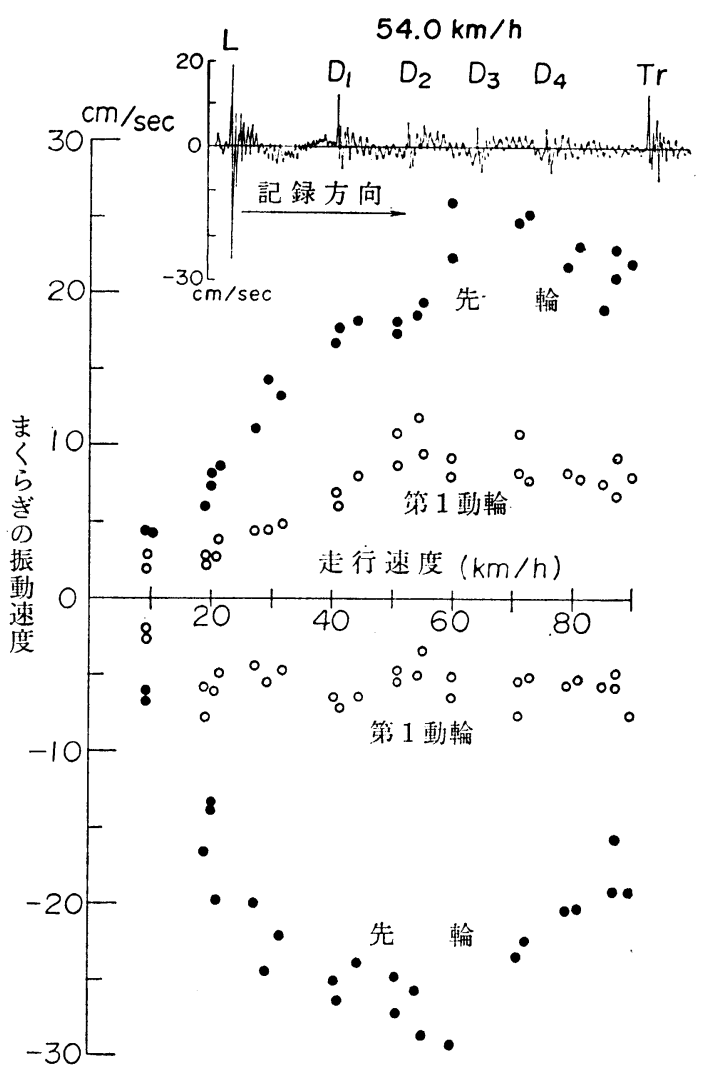

－5 空転伤によるまくらぎの振動速度 
と静荷重との比は図一4の右に示した数值よりはるかに 大きくなると推定される。

空転傷の下にあるまくらぎに振動速度計を取付けて機 関車通過時の振動速度を測定した結果を図一5 の上に示
した。先輪の車輪荷重は $3.5 \mathrm{t}$ であり, 第 1 動輪は 7.1 $\mathrm{t}$ であるが, 重量の軽い車輸の下では振動速度が非常に 大きくなっている。走行速度とまくらぎの振動速度との 関係を 図一5 の下に示したが，走行速度が $60 \mathrm{~km} / \mathrm{h}$ の

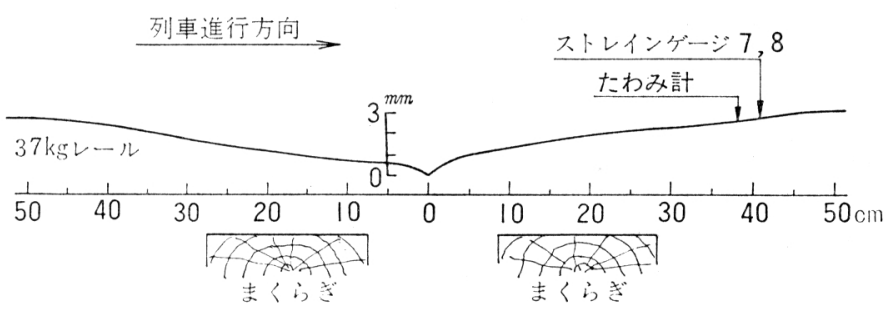

図一6 レール継目落の形状

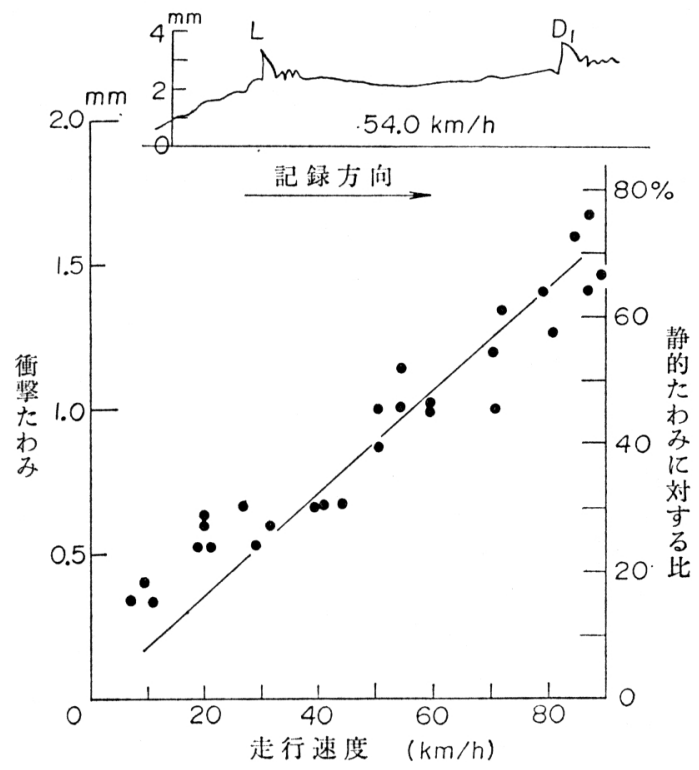

図一7＼cjkstart継目落によるレールの衝撃たわみ

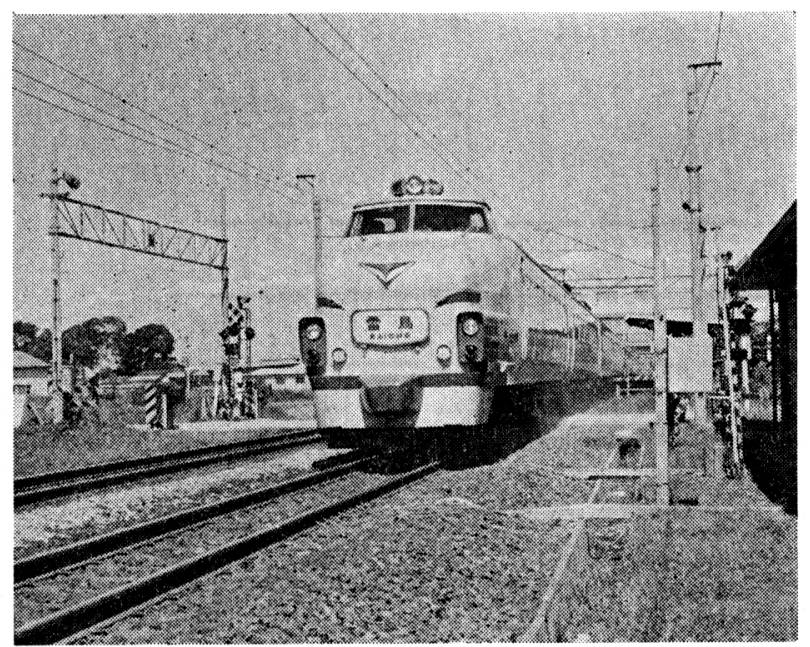

写真-1 車輪荷重の測定箇所
ときにまくらぎの振動速度が最大となっ ている。

次に図一6に示すごときレール継目落 を機関車が通過するときレールに生ずる たわみを測定し，その結果の一例を図一 7 の上に示した。先輪が通過するときの 衝撃たわみの大きさと走行速度との関係 を図一7の下に示した。走行速度に比例 して衝撃たわみの増加することが認めら れる。 $90 \mathrm{~km} / \mathrm{h}$ において衝撃たわみは静的たわみの 73 \%に達している。さきの測定結果に比較すればレール 継目落のごとく車輪の直径に近い延長をもつ軌道不整 部においては列車速度に比例する衝撃を受けるが, 空転 傷のごとく延長の短かい不整部においては走行速度の増 加とともに衝撃が減少するようである。しかし振動の測 定においては延長の短かい不整部といえども走行速度と ともに振動速度の増すことが観測された。

\section{3. 車輪踏面の傷によって生ずる衝擊の測定}

走行車両の車輪踏面の傷によって軌道が受ける衝撃の 大きさを知る目的をもって北陸線野々市駅付近（米原起 点 $179.360 \mathrm{~km}$ ) 上り線において走行車両のすべての車 輪荷重を測定した。線路状態は写真一1に示すごとく直 線 $2.5 \%$ 上り勾配，約 $1 \mathrm{~m}$ の築堤区間である。 $50 \mathrm{~kg}$ N レールによる延長 $1500 \mathrm{~m}$ のロングレール区間であ り，PC 3 号 5 型まくらぎが $25 \mathrm{~m}$ 当り 39 丁配置され ていた。砕石道床の厚さはまくらぎ下 $250 \mathrm{~mm}$ となっ ていた。

同一のまくらぎ間合に $32 \mathrm{~cm}$ の間隔をもって レール腹部に 2 枚の直交 2 軸ワイヤストレイン ゲージを貼付け, 図一8に示すように接続した。 この方法でこれら 2 点におけるせん断応力の差を 検出することができた。このようにして求めたせ ん断応力の差はこの間においてレールが受ける重 直荷重に比例するのでこの間のどの位置に衝撃が

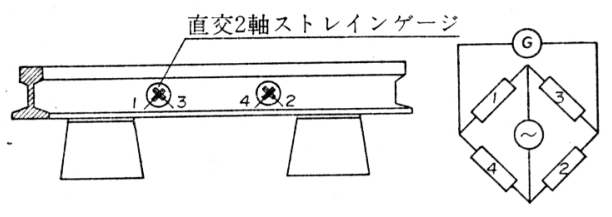

図一8 レールのせん断ひずみによる 車輪荷重の測定法 


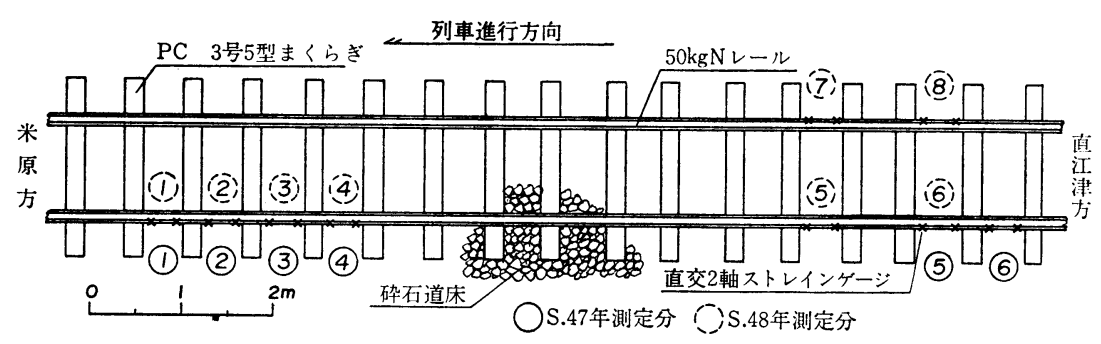

図一9 車輪荷重の測定笛所（北陸本線 $179360 \mathrm{~m}$ 付近上り線）

加わっても一定の倍率で衝撃力の大きさを知ることがで きる ${ }^{8)}$ 。

図一9 に示すごとく連続 4 個のまくらぎ間合いおよび いくらか離れた 2 間合いで測定したので直径 $86 \mathrm{~cm}$ の 車輪に対しては 図一10 に示すごとく全周の $65 \%$ を検 出することができた。レールに垂直荷重と同時に横圧力 が加わるときにはレール腹部の両側にゲージを貼り付け てその平均值を求めなければならないが，今回の測定箇 所は直線であり，横圧力はほとんど認められなかった。

測定記録より車輪荷重の大きさを決める方法としては 静的に荷重を加えて基準值を求める方法むあるが，今回 は車輪荷重がほぼ正確にわかっている車両たとえば EF 70 形式機関車の記録を基準 として他の車両の車輪荷重

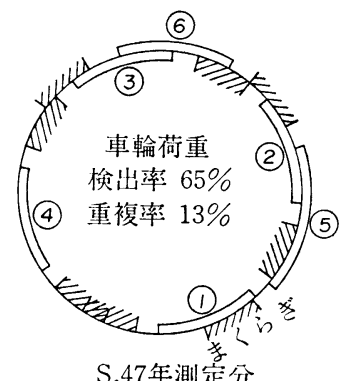

$\mathrm{S} .47$ 年測定分

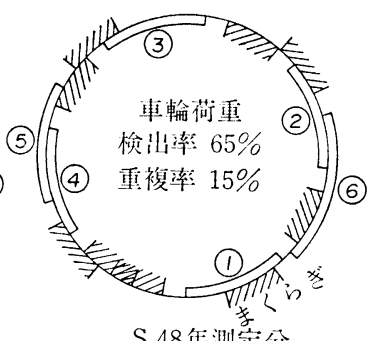

S.48年测定分
図一10 車輪荷重の測定率（車輪の直径 $86 \mathrm{~cm}$ の場合）
を求めた。

測定記録の数例を 図一11〜16 に示す。図一11 は特急 電車最後部の 2 両の通過時の記録であり, (1)の間合いで はクハ 481 形式車両の運転台より最も離れた車輪によっ てレールに $16 \mathrm{t}$ に達する荷重の作用したことが認めら れ, これは静的車輪荷重の 3.8 倍に相当する。また (3) の間合いでは 1 個の車輪荷重がほとんど 0 となってい る。このようにクハ 481 形式車両の通過時にレールに加 わる車輪荷重の変動の激しいことはこの車両の車輪踏面 に大きな傷があったことを示している。この形式の車両 において車輪踏面に傷を発生し易い理由についてはすで に前報告 ${ }^{1)}$ において述べたところである。

図-12 は特急電車の食堂車 (サシ 481 形式) とグリ ーン車（サロ 481 形式）通過時の記録であり,一般に 食堂車の車輪の通過時には車輪荷重の変動の激しいこと が認められる。特に (5)の間合いでは $23 \mathrm{t}$ の車輪荷重を 生じた場合があり, 静的車輪荷重の 4.8 倍に達する。こ れは車輪に大きな平坦部があったことを示している。こ のように食堂車の車輪に傷の多い理由は水槽が車体の中 央より外れて取付けられており，水が空になったときに 前後台車に輪重の差を生ずるためと考えられる。

図一13 はディーゼル特急のキロ 80 形式およびキハ 82 形式車両の通過時の記録である。キハ 82 形式車両通 過時にはほとんど衝撃が認められないが，キロ 80 形式

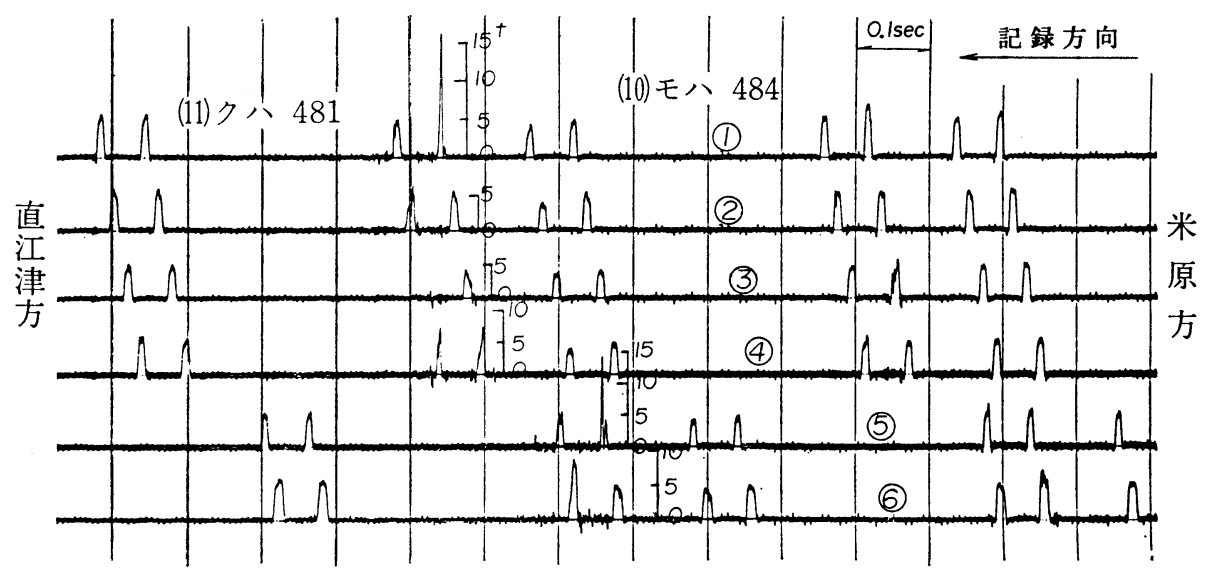

図一11 車輪荷重の測定記録 (4020 M $126.0 \mathrm{~km} / \mathrm{h}$, 昭.47.8.30 測定) 


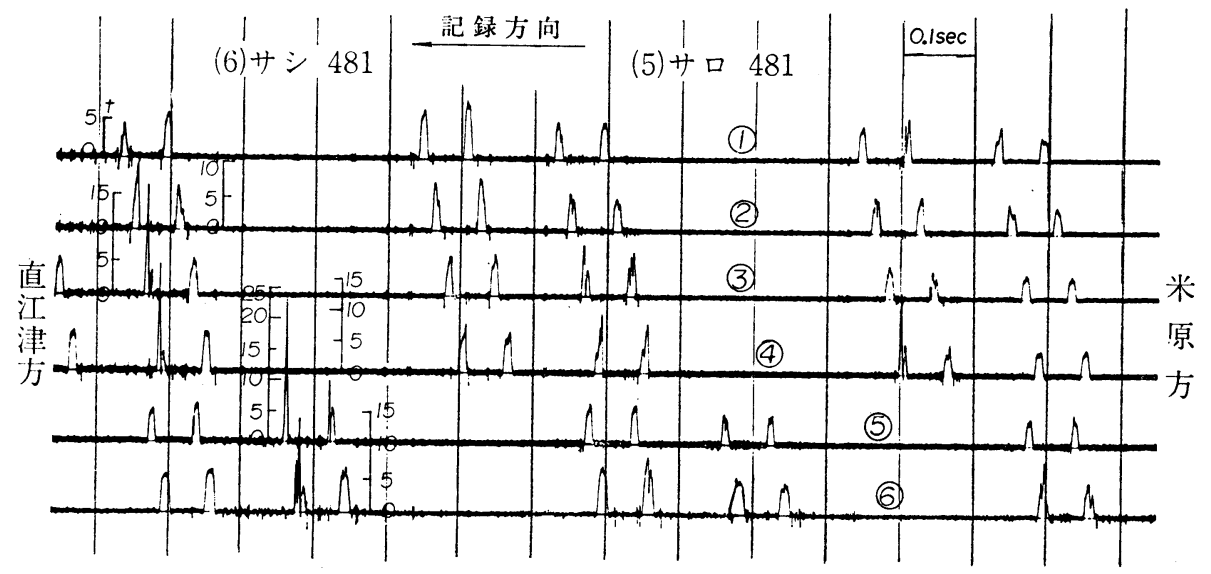

図一12 車輪荷重の測定記録（4022 M $121.4 \mathrm{~km} / \mathrm{h}$, 昭.47.8.30 測定）

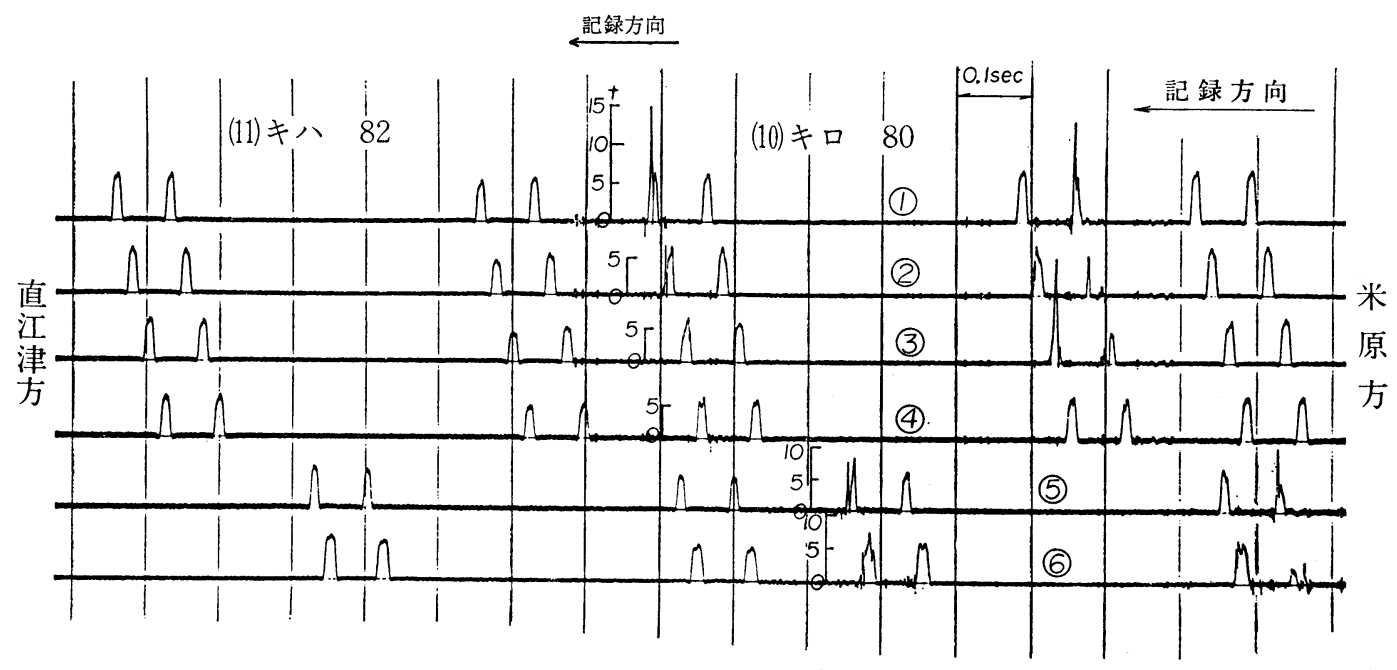

図一13 車輪荷重の測定記録（4002 D $102.2 \mathrm{~km} / \mathrm{h}$, 昭.47.8.30 測定）

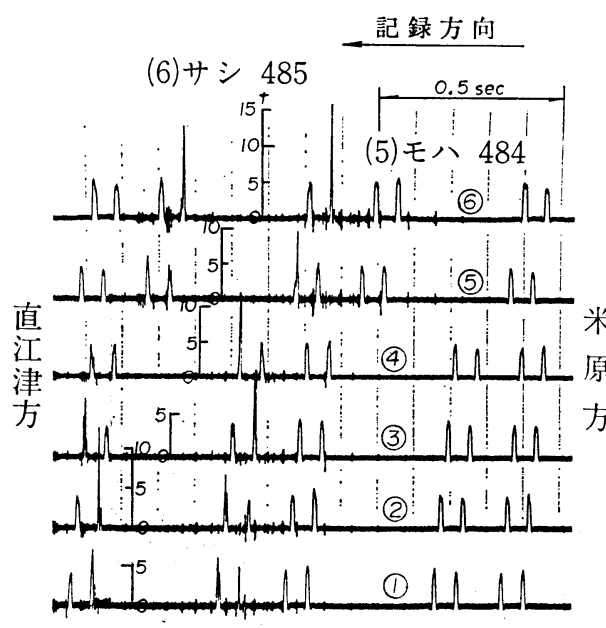

図一14 車輪荷严の測定記録 (4 002M $127.3 \mathrm{~km} / \mathrm{h}$, 昭.48.8.1 測定）

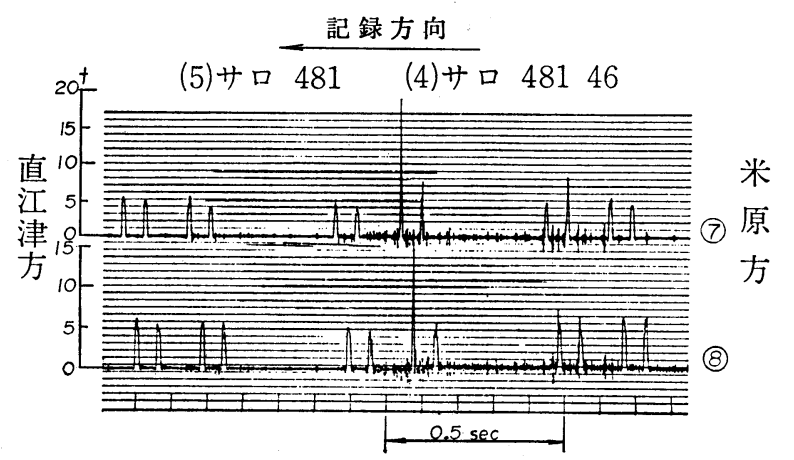

図一15 車輪荷重の測定記録 (4016 M $129.7 \mathrm{~km} / \mathrm{h}$, 昭.48.8.2 測定） 
記録方向

(2) モハ470

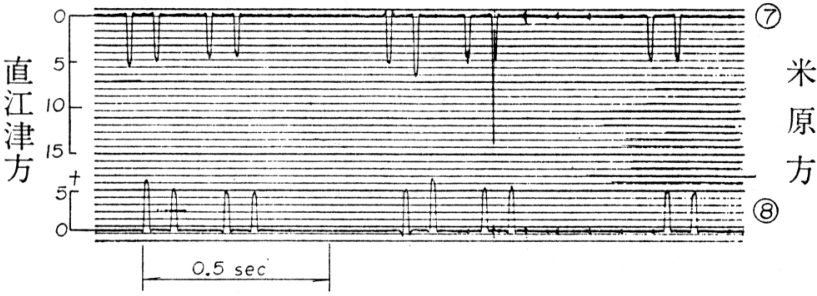

図一16 車輪荷重の測定記録（1702 M $102.9 \mathrm{~km} / \mathrm{h}$, 昭. 48.8 .2 測定）

図一15，16 にはサロ 48146 およびクハ 45559 通過時にレールが受けた衝撃を示し，写真一2， 3 にこれら車輪の踏面に発見された傷を示す。 このような傷の存在によって軌道は大きな衝撃 を受けたことが判明する。

\section{4. 衝撃による車輪荷重変動の頻度}

各種の車両が走行中において軌道に及ぼす輪 重変動の発生頻度を知るため, 多数の通過列車 の車輪荷重を測定し，その結果を車両の形式ま

車両の通過時には多数の衝撃が認められる。キハ 82 形 たは自重によって区分し，横軸に車輪荷重をとり，縦軸 にそれ以下の車輪荷重が発生する累積頻度を対数目盛で 示した。

図一17 は車両重量が 40４2 $\mathrm{t}$ の電動車両の車輪荷重 いて車輸䠌面に多くの傷が発生寸ることをあらかし る。

図一14 はモ八 484 形式およびサシ 485 形式車 両通過時の記録であるが，サシ 485 形式車両（食 堂車)においてはすべての車輪踏面に傷があるも ののごとく，いずれかのまくらぎ間合いにおいて 衝撃があらわれている。

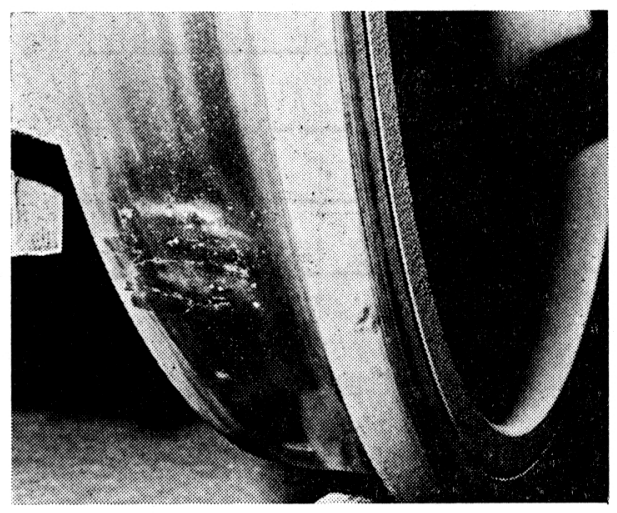

写真一2 車輪踏面に生じた傷（クハ 45559）

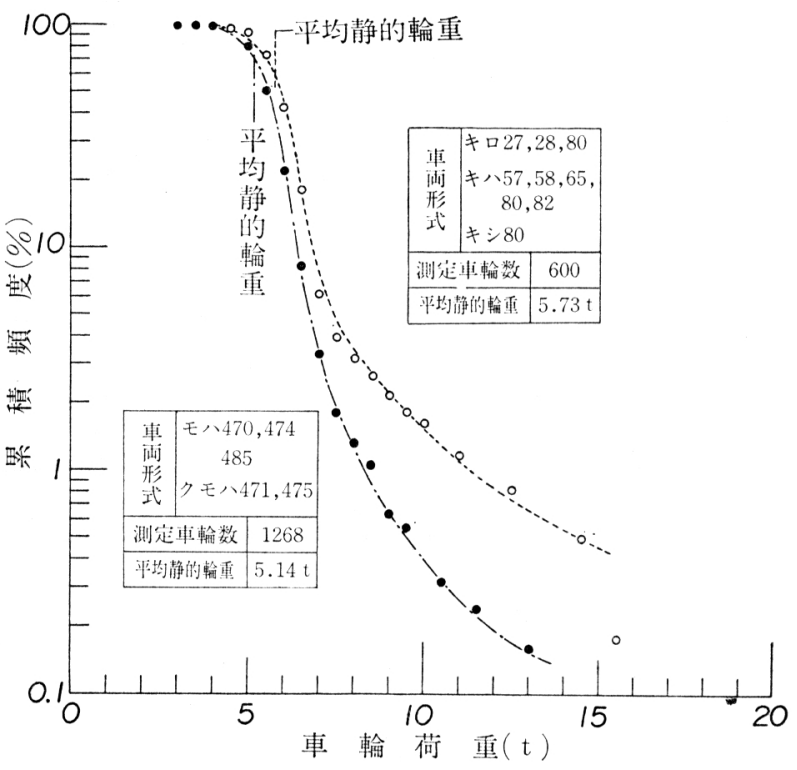

図一17動力車両の車輪荷重-累積頻度曲線
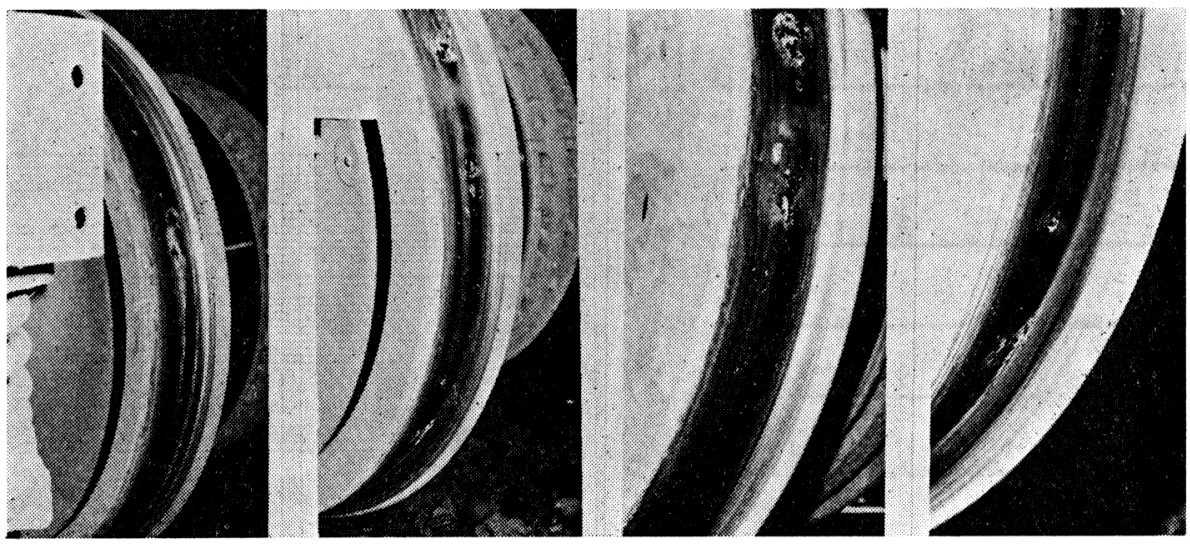

写真一3 車輪踏面に生じた傷（サロ 48146） 


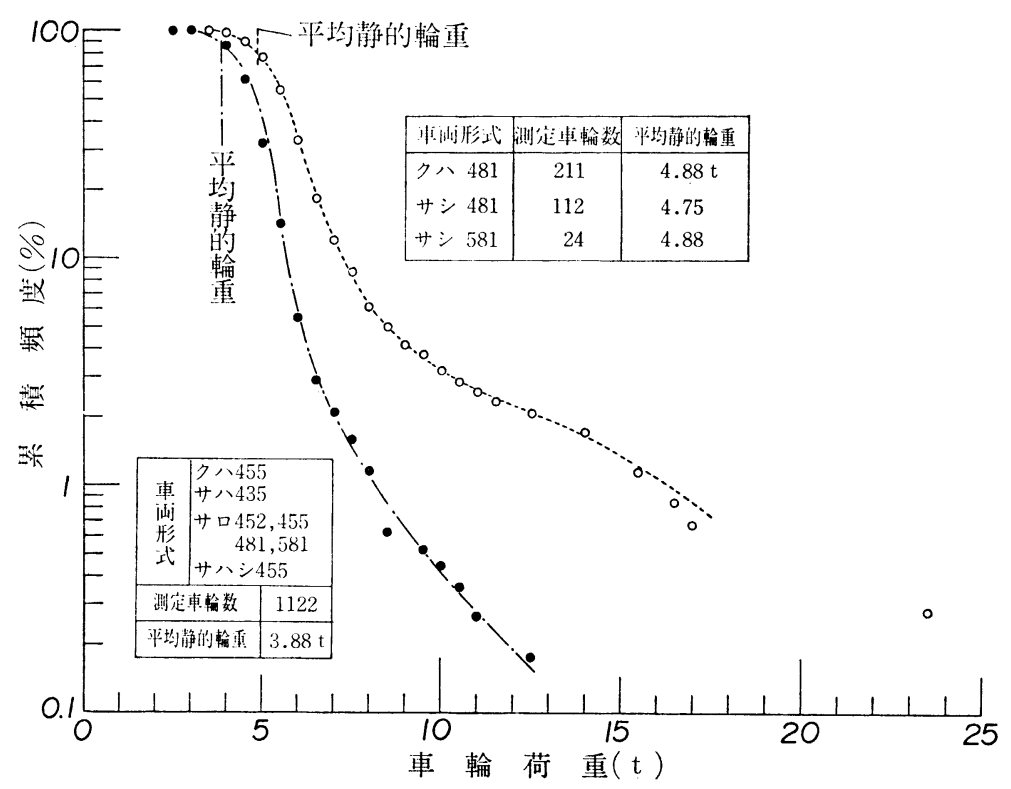

図一18 付随車両の車輪荷重-累栍頻度曲線
によればばね下重量が大きいほど 衝撃が大きいとされていたが，今 回の実験ではこれと反対の結果に なった。レール面の傷または軌道 の不整によって生ずる衝撃はばね 下重量の大きさに比例することも あり得るが，車輪踏面の傷は車輪 荷重が小さいほど発生し易く, 特 に前後の台車に作用寸る車体重量 に差がある場合には軽い台車の下 で発生して軌道に大きな衝撃を加 えることとなる。

\section{5. 車両の動摇による車輪 荷重の変動}

図一9 に示すごとく同一まくら ぎ間合いで左右レールに生ずる車 輪荷重を同時に測定した区間では
表一1 累程頻度の $1 \%$ となる車輪荷重および衝俥

\begin{tabular}{|c|c|c|c|c|}
\hline & \multirow{2}{*}{ 電動車 } & \multirow{2}{*}{ 気 動 車 } & \multicolumn{2}{|c|}{ 付 随 } \\
\hline & & & 一 般 & \begin{tabular}{|lc} 
クハ & 481 \\
サン & 481,581
\end{tabular} \\
\hline 1\% 車輪荷重 & $8.2 t$ & $11.6 \mathrm{t}$ & $8.3 \mathrm{t}$ & $16.0 \mathrm{t}$ \\
\hline 静的車輪荷重 & 5.1 & 5.7 & 3.9 & 4.9 \\
\hline 衝擊 & 3.1 & 5.9 & 4.4 & 11.1 \\
\hline 比 & 0.61 & 1.03 & 1.13 & 2.26 \\
\hline
\end{tabular}

を 1268 個測定した結果より車輪荷重と累積発生頻度と の関係を・印で示した。また自重が 40〜50 t のディー ゼル動車の車輪荷重を 600 個整理して○印で記入した。 これら車両の走行速度は $100 \sim 120 \mathrm{~km} / \mathrm{h}$ であった。同 様に付随車両を自重が $30 \mathrm{t}$ 前後の車両群と $39 \mathrm{t}$ 前後の 車両群とに区分して・印および○印で図一18に示した。 この場合の走行速度は $120 \mathrm{~km} / \mathrm{h}$ 程度であった。これら の図において 輪重一累積頻度曲線 の傾きが緩いほど軌道に与える衝 撃の発生頻度が大きいことを意味 し, 走行車両の形式によって大い に異なることが認められる。これ らの図から累積頻度の $1 \%$ となる 車輪荷重を求め, この車輪荷重か ら静的車輪荷重を差引いた値を衝 撃として表一1に示した。

この表によれば付随車による衝 撃は電動車に比べて大きく，特に ク八 481 , サシ 481,581 形式電 車による衝撃は静的車輪荷重の 2.26 倍に達している。従来の説
各車輪による荷重の大きさとその車両の平均車輪荷重と の差によって車両の動摇による荷重の変動を知ることが できる。ただし明らかに車輪踏面の久陥によると推定さ れるものは除いた。

特急電車 1 編成について車輪荷重の変動を測定した結 果の一例を図一19 に示した。車輪荷重の大きさを 100 $\mathrm{kg}$ ごとの階段で分類し，その分布を正規確率紙によっ て検定したところほぼ一直線となり，正規分布であるこ とが判明した。

測定地点を通過した特急電車 5 個列車について車輪荷 重の変動を調べた結果を 図一20 に示す。この図で・印 は電動車であり，その標準偏差は $600 \mathrm{~kg}$ となった。ま た○印はクハ 481 形式およびサシ 481 形式車両であり, その標準偏差は $740 \mathrm{~kg}$ となった。数理統計論によれ
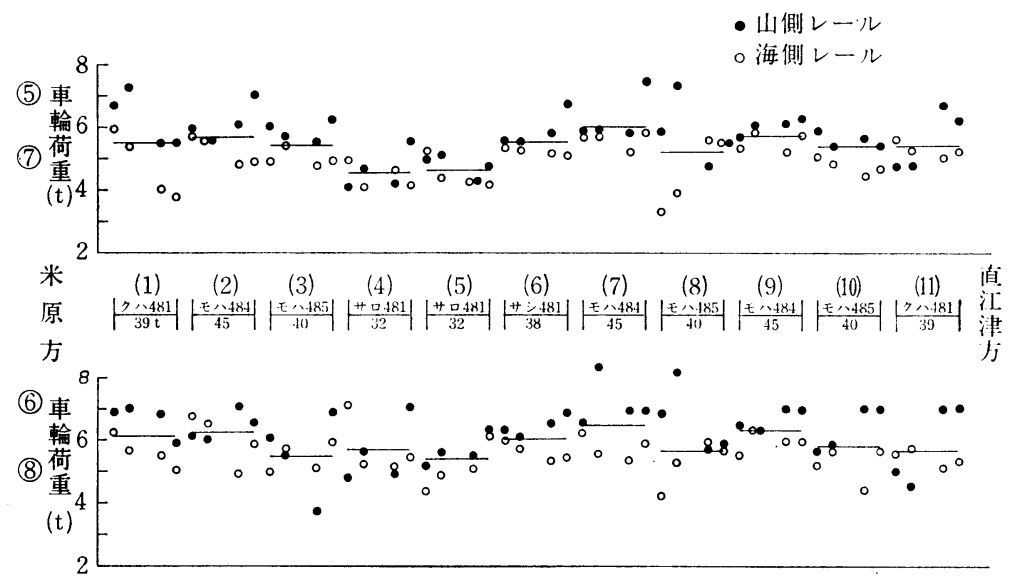

図一19 特急電車1編成の車輪荷重変動 $(4020 \mathrm{M} 130.5 \mathrm{~km} / \mathrm{h}$, 昭.48.8.2 測定) 


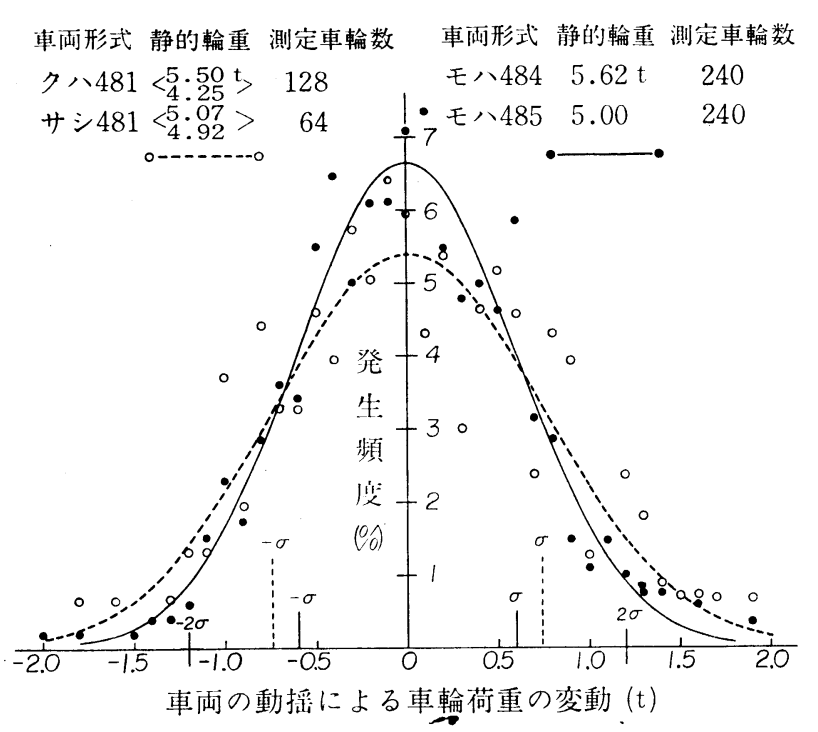

図一20車両の動摇による車輪荷重の分布

ば, 全測定值の $1 \%$ は平均值に比べて標準偏差の 2.33 倍以上大きくなることが示されている。上記の標準偏差 の 2.33 倍はそれぞれ $1.4 \mathrm{t}$ および $1.7 \mathrm{t}$ となる。表一 1 によれば累積頻度が $1 \%$ におけるこれらの車両の車 輪荷重と平均荷重との差は $3.1 \mathrm{t}$ および $11.1 \mathrm{t}$ となっ ていることに比較すれば車両動摇が軌道に及ぼす影響は 車輪踏面の傷によって生ずる影響に比へててはるかに少な いといらことができる。

\section{6. 理論的考察}

車輪またはレールの走行面に不整部が存在する場合に 軌道が受ける衝撃の大きさを計算する式がこれまでにも いくつか発表されているが4),9), 本文では衝撃の前後に おける車輪の運動量の変化より衝撃を求める式を誘導し た。

車輪踏面に延長 $l$ のラット部をもつ半径 $r$ の車輪に 対してその走行速度が十分低いと仮定して車軸中心の軌 跡を描けば 図一21 の実線 $\mathrm{OC}$ で示すごとく $\mathrm{A}$ 点を中 心とした半径 $r$ の円弧となる。車輪が $\mathrm{B}$ 点においてレー ル面に打撃を加えた後には車軸中心の軌跡は実線 $\mathrm{CE}$ で示すごとく $\mathrm{B}$ 点を中心とした半径 $r$ の円弧となる。車 軸中心の軌跡は $\mathrm{C}$ 点において急にその方向が変化するの で車輪の上下方向の運動量の変化より $\mathrm{B}$ 点における衝撃 （力積） $P$ の大きさを計算すれば

$$
P=M v \frac{l}{r}
$$

となる。ここに $M$ は車輪の質量であり, $v$ は走行速度 である。車両の走行速度が次第に大きくなれば車輪は一 時レール面から離れ, 車軸の中心は破線のごとき軌跡を

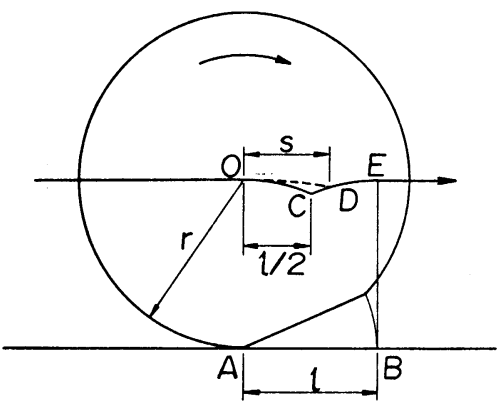

図一21 フラット部を生じた車輪の車軸中心の軌跡

描くことになる。車輪がレール面を離れている間 の車輪の上下動に関しては次の微分方程式が成立 する。

$$
M \frac{d^{2} z}{d t^{2}}=g(M+W)
$$

ここに $W$ は軸箱を通して車輪を上から押さえて いる車体の荷重である。 $M+W$ が静的車輪荷重 となる。 $z$ は車軸中心の下方向の移動量である。曲線 $\mathrm{OD}$ の曲率半径 $R$ は次式によって計算される。

$$
\frac{1}{R}=\frac{g}{v^{2}}\left(1+\frac{W}{M}\right)
$$

$R>r$ となれば車輪はレール面を離れて走行するこ とになる。 $R<r$ となることはあり得ないからこのと きには車輪は常にレール面に接触してさきに述べたごと く車軸の中心は OCE 線上を移動する。この臨界速度を $v_{c}$ とすればこれは次式によって計算される。

$$
v_{c}=\left\{g r\left(1+\frac{W}{M}\right)\right\}^{1 / 2}
$$

車両の進行速度が臨界速度以上となるときには車軸の 中心が 図一21の D点に到達したときに車輪は B 点に打 揧を加えることになる。OD の距離を $s$ とすれば $s$ は 次式を解いて求められる。

$$
\frac{s^{2}}{2 R}=\frac{(l-s)^{2}}{2 r}
$$

これより

$$
s=l \frac{v}{v+v_{c}} .
$$

車軸中心が $s$ の距離を進むに要する時間は $s / v$ とな るのでこのときの車軸中心の下向きの速度 $V$ は

$$
V=g(M+W) \frac{s}{v}=g l \frac{M+W}{M\left(v+v_{c}\right)} .
$$

車軸中心は $\mathrm{D}$ 点に到達した後円弧 $\mathrm{DE}$ に沿って進行 するのでこの時点における上向きの速度 $V^{\prime}$ は

$$
V^{\prime}=v \frac{l-s}{r}=l \frac{v v_{c}}{r\left(v+v_{c}\right)}
$$

となる。したがって $\mathrm{B}$ 点に加えられる衝撃の大きさ $P$ は

$$
P=M\left(V+V^{\prime}\right)=M v_{c} \frac{l}{r}
$$


となり，車両の走行速度 $v$ とは無関係になる。

以上の計算結果によれば車両の速度が式 (4)によって 決定される臨界速度以下のときには衝撃の大きさは車両 の走行速度に比例し，これ以上になれば一定值となる。 またいずれの場合にも衝撃の大きさはフラット部の長さ に比例することが示されている。

ク八 481 形式車両を例にとり, $r=43 \mathrm{~cm}, M=560$ $\mathrm{kg}, W=4320 \mathrm{~kg}$ とすれば, $v_{c}=606 \mathrm{~cm} / \mathrm{sec}$ が得られ る。これは $22 \mathrm{~km} / \mathrm{h}$ の速度に相当する。またフラット 部の長さを $50 \mathrm{~mm}$ とすれば臨界速度以上における衝撃 の大きさは式 (9) により $P=39400 \mathrm{~kg} \cdot \mathrm{cm} / \mathrm{sec}$ となる。

これまでに人工的に車輪踏面に延長 $50 \mathrm{~mm}$ のフラッ ト部を作り, 衝撃を測定したところ $20 \sim 30 \mathrm{~km} / \mathrm{h}$ の速 度になるまでは車輪圧力およびレールに生ずる曲げ応 力が増加するが, それ以上の速度になれば増加がとまり ほぼ一定值になるとの報告があり ${ }^{4)}$, 以上の計算結果は この実験結果をよく説明することができる。

以上の計算式はレールのたわみの変化を考慮せず, レール面は常に一定の高さに保たれていると仮定して導 いたものである。しかし実際にはレール面に加わる荷重 が減少すればレールのたわみが減少するので $R>r$ と なったときにただちに車輪がレール面を離れるか否かに 疑問がある。車輪がレール面を離れずにレールより上向 きの力を受けていればその力だけ式 (2) の右辺より差 引かれるので $R$ は式 (3) で求められた值より大きくな る。したがって車輪がレール面に加える衝撃は式 (9) で 示された值より小さくなる。しかし特にフラット部の延 長が大きくない限りこの影響は無視してよいと考えられ る。

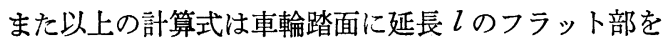

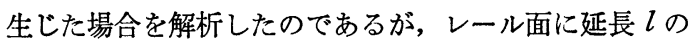
空転傷が存在する場合に対してもこの計算式はそのまま 適用することができる。

レール継目落に対してはこの形状を負の指数関係で あらわす方法もあるが9,10)，一般にその曲率が小さいの で単なる勾配変わりと見なしても差支えない。継目部を 中央において延長 $l$ の区間で $h$ の落込みがある場合に

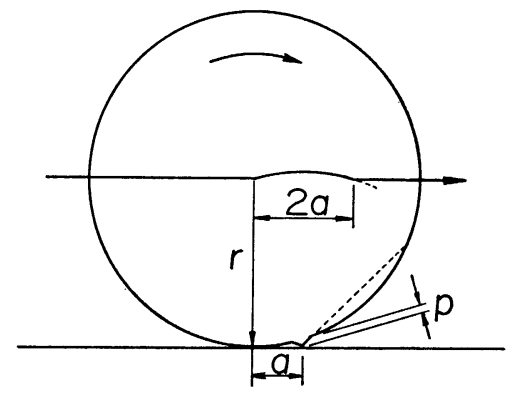

図一22 突起部を生じた車輪の車軸中心の軌跡
車両の走行速度を $v$ とすれば衝撃の大きさ $P$ は

$$
P=4 \mathrm{Mvh} / \mathrm{l}
$$

となり, 走行速度に比例する。

次に図一22 に示すごとく車輪踏面に高さ $p$ の突起 部が存在する場合を考察する。車輪とレールとの接点が 突起部の手前 $a$ の距離にあるときには突起部はレール面 に打撃を加える。車軸の中心はこのとき急にその進行方 向を変えてその軌跡は 図一22 に示す円弧となる。打揧 直後における車軸中心の上向きの速度 $V^{\prime}$ は

$$
V^{\prime}=v \frac{a}{r}
$$

となる。しかるに

$$
a=\sqrt{2 r p}
$$

であるから車輪の質量を $M$ とするとき衝撃の大きさ $P$ は

$$
P=M V^{\prime}=M v\left(\frac{2 p}{r}\right)^{1 / 2}
$$

となる。

$p=0.01 \mathrm{~cm}, r=43 \mathrm{~cm}, M=560 \mathrm{~kg}$ とし, 車両の走 行速度を $120 \mathrm{~km} / \mathrm{h}$ とすれば式 (11) より $V^{\prime}=72 \mathrm{~cm} /$ $\mathrm{sec}$, 式 (13) より $P=40300 \mathrm{~kg} \cdot \mathrm{cm} / \mathrm{sec}$ が得られる。 以上の計算によれば車輪の踏面にわずかに $0.1 \mathrm{~mm} の$ 突起部があるだけで車両の速度が $120 \mathrm{~km} / \mathrm{h}$ になれば車 輪が $72 \mathrm{~cm} / \mathrm{sec}$ の速度でレールにつき当たったことと同 様な打撃を加えることになる。これは車輪を $26 \mathrm{~mm}$ の 高さからレール面に落したときの落下速度に等しく, 試 験軌道で行った実験 ${ }^{11}$ によれば $10 \mathrm{t}$ 以上の衝撃力を発 生することになる。またここに得た衝撃の大きさは延長 $50 \mathrm{~mm}$ のフラット部によって生ずる衝撃の大きさにほ ぼ等しくなる。

それでは実際の車輪に突起部があり得るかということ になるが，車輪がレール面上をすべり，車輪踏面にフ ラット部を作る過程において摩擦熱のために踏面が溶融 して平坦となると同時に 図一22 に示すごとく溶融部が 進行方向と反対に移動して突起部を作るのではないかと いう説がある。このような突起部によってレール面に周 期的に打撃痕を作った例も報告されている ${ }^{4)}$ 。もし車輪 踏面に突起部があるとしてもその高さが $0.1 \mathrm{~mm}$ 程度 であってこれがフラット部に隣接しているとなればその 存在を識別し，その高さを測定することは非常に困難で あろう。しかし $100 \mathrm{~km} / \mathrm{h}$ 以上で走行する車両の車輪 によって軌道にしばしば非常に大きな衝撃が加えられた 事実は車輪のフラットだけでは説明することが困難で突 起部の存在を仮定することによって始めて了解される。

\section{7. 結}

\section{論}

鉄道線路においてレール面または車輪踏面に傷または 
欠楩があるときに走行車両によって軌道に大きな衝撃が 加えられることはこれまでにも多数の実験によって確か められたところである。今回は主として在来線の線路お よび一般の通過車両について衝撃の大きさの測定および 発生頻度の集計を行った。

レール面に空転傷のごとく延長の短い欠陥部が存在す るときには $20 \sim 30 \mathrm{~km} / \mathrm{h}$ の速度で列車が走行するとき に軌道に最大の衝撃を加えるが，高速になるとその影響 が次第に小さくなる。しかしレール継目落のごとく車 輪の直径と同程度の延長をもつ久宿部があるときには列 車の速度にほぼ比例する衝撃を加えることが判明した。

これまでには人工的に車輪踏面にフラット部を作り， 軌道に加わる衝撃を測定した結果が発表されているが, レール応力およびレール圧力は列車速度 $30 \mathrm{~km} / \mathrm{h}$ 付近 で最大となり, その後 $100 \mathrm{~km} / \mathrm{h}$ になるまでの間で次第 に低下することが報告されている4)。以上を併せて考察 すればレール面または車輪踏面に延長の短いくぼみまた は平坦部を作ったのでは高速列車の車輪はこの上を飛び 越えるので大きな衝撃を加えることはあり得ないと考え られる。しかるに今回実際の線路で一般の走行列車によ る衝撃を測定した結果によれば速度 $120 \mathrm{~km} / \mathrm{h}$ において 静的車輪荷重の $2 \sim 5$ 倍に達する車輪荷重を発生した場 合もしばしば認められた。特にクハ 481 , サシ 481,581 形式車両のごとく前後の台車に加わる車体の重量に差を 生ずる場合には車輪踏面に傷を発生する可能 性が大き く, 測定数の $3 \%$ は $10 \mathrm{t}$ 以上寸なわち静的車輪荷重の 2 倍以上の車輪荷重となり, また $1 \%$ は $16 \mathrm{t}$ 以上すな わち静的車輪荷重の 3.3 倍以上となった。

このように一般の走行列車によっては従来の実験では 得られなかった大きな衝撃があらわれた理由は何による かについて現在の段階では十分解明することはできな い。しかし車輪がレール面をすべり, 踏面にフラット部 を生じた場合には摩擦熱のために踏面が溶融して平坦部 を作ると同時に溶融部が進行方向と反対側に移動して突 起部を作るのではないかと想像され，これを実証した報 告も出ている ${ }^{4)}$ 。車輪踏面に突起部があるときには走行
速度に比例した衝撃を加えるであろらことは容易に証明 される。また従来の実験ではレール底部に生ずる曲げ応 カまたはレール圧力より衝撃の大きさを求めていたが, 今回の測定においてはレールに生ずるせん断力より直接 車輪荷重を求めたことも大きな衝撃の得られた原因と考 えられる。

車輪荷重の変動は車両の動摇によっても生ずるが, ク 八 481 およびサシ 481 形式車両について動摇による影響 を測定した結果によれば測定数の $19 \%$ が静的車輪荷重の 1.35 倍以上の車輪荷重となり, 軌道に加える負担から 見れば車輪踏面の傷によるものに比べてはるかに少ない といらことができる。

終りに現場測定に当たって金沢鉄道管理局金沢保線区 および金沢運転所の方々より多大のご協力を受けたこと を述べ,ここに厚く感謝の意を表する。

\section{考文 献}

1）小野一良・伊藤義男 : 鉄道線路の軌道に生ずる振動の解 析, 土木学会論文報告集, 第 179 号, 昭 45.7.

2）佐藤 裕・大月隆士：タイヤフラット試験, 鉄道技術研 究所速報, No. 61-379, 昭 36.12 .

3）佐藤 裕・豊田昌義: 車輪フラットの軌道に与える影響, 鉄道線路, 第 12 巻第 7 号, 昭 39.7 .

4）佐藤 裕・豊田昌義：高速列車による軌道の変形, 鉄道 技術研究所報告, No. 492, 昭 40.8 .

5）八十島義之助：継目衝撃に関する研究，土木学会論文集， 第 51 号, 昭 32.12 .

6）佐藤吉彦ほか 6 名: 951 形式電車に関する 1970 年にお ける 地上試験, 鉄道技術研究所速報, No. $71-178$, 昭 46.9.

7) 佐藤吉彦: 東海道新幹線において 951 形式試験電車に発 生した著大輪重の原因とその対策，鉄道技術研究報告, No. 824 , 昭 47.9 .

8）棚橋 宏: 輪重・横圧の新測定法, 鉄道線路, 第 18 巻 第 9 号, 昭 45.9 .

9）佐藤 裕：軌道に加わる垂直衝撃圧力，鉄道技術研究報 告, 第 16 号, 昭 33.7 .

10）小野一良 : 軌道応力計算法の一考察 (軌條接目部), 業務 研究資料, 第 26 巻第 6 号, 昭 13.3 .

11）小野一良・伊藤義男：砂利道床軌道が受ける衝撃の測定 および解析, 土木学会第 28 回年次学術講演会講演概要集 第 4 部, 昭 48.10 .

(1974.11.21 · 受付) 